\title{
Assessment of Performance and Suitability of Different Castor Hybrids (Ricinus communis L.) in Central Dry Zone of Karnataka, India
}

\author{
Muneshkumar $^{1}$, V. Kugati ${ }^{1}$, Basavalingaiah ${ }^{2}$, L.B. Ashok ${ }^{3 *}$, \\ M. Dineshkumar ${ }^{1}$ and S. Raveesha ${ }^{3}$
}

${ }^{1}$ Department of Agronomy, College of Agriculture, Shivamogga, India

${ }^{2}$ Extension Education Unit, Madikeri, 571 201, India

${ }^{3}$ Department of NRM, College of Horticulture, Hiriyur 577 598, India

University of Agricultural and Horticultural Sciences, Shivamogga, India

*Corresponding author

\section{A B S T R A C T}

Keywords

Elemental sulphur,

Single

superphosphate, $\mathrm{DCH}-$ 177, YRCH-1, HCH-6

Article Info

Accepted:

04 July 2019

Available Online:

10 August 2019
A field experiment was carried out at Zonal Agricultural and Horticultural Research Station, Hiriyur, Karnataka to during Kharif 2016-17 to assess the performance and suitability of different Castor hybrids (Ricinus communis L.) and to identify good castor hybrid in Central Dry Zone of Karnataka. The treatment comprised of 3 different hybrids and 3 sources of sulphur fertilizers (Single superphosphate, Gypsum and Elemental sulphur) in Randomized Block Design with 3 replications. The results showed that the castor hybrid DCH- 177 with the application of $20 \mathrm{~kg}$ sulphur per hectare through gypsum recorded significantly higher seed yield $(1388.8 \mathrm{~kg} / \mathrm{ha})$ compared to YRCH-1 (1250.9 kg/ha) and HCH-6 (1200.2 kg/ha).

\section{Introduction}

Castor (Ricinus communis L.) is a non-edible, industrial oilseed crop, which plays an important role in Indian economy.

The crop is well known for its non-edible oil (45-50\% oil in seeds), which is completely biodegradable with its tremendous uses. India plays a lead role in the production and productivity of castor in the world with a production of 2.34 million tones seeds while China, producing 0.18 million tones of castor is the second largest producer (Anonymous, 2015). Cultivation of castor in India has mainly been confined to Gujarat, Andhra Pradesh, Telengana, Rajasthan and Tamil Nadu. Sulphur plays an important role in the formation of amino acids, synthesis of proteins, chlorophyll, oil content and nutritive quality (Jamal et al., 2009).

Sulphur has become one of the major limiting nutrients for oilseed crop production in recent years due to its widespread deficiency (Singh and Singh, 1999). Sulphur deficiency is 
responsible for stunted growth of the crop and subsequent reduction in the yield and quality of the crop (Singh, 1991). Use of non-sulphur fertilizers in intensive agricultural activities results soil sulphur deficiency in the country. On an average, oil seed crops including castor absorbs as much sulphur as they absorb phosphorus. Productivity of oil seed crops can be increased by application of sulphur (Tandon, 1995).

Considering this, the present study was undertaken to find out the effect of various sources and doses of sulphur on the performance of Castor under rainfed conditions of Karnataka.

\section{Materials and Methods}

Field experiment was conducted for the year (2016-17) during the Kharif season at Zonal Agricultural and Horticultural Research Station, Hiriyur, Karnataka to assess the response of Castor to sulphur application and to identify good source of sulphur for higher seed and oil yield under black soil.

The Initial soil nutrient status: $\mathrm{pH}$ of 7.9 , medium available nitrogen (220 kg/ha), medium available phosphorus $(21.4 \mathrm{~kg} / \mathrm{ha})$ and potassium (212.4 kg/ha), Zinc (0.20 ppm), Iron (4.56 ppm), Sulphur (2.5 ppm) and Manganese (15.9 ppm).

The experiment consists of 12 treatments, the treatments comprised from two sulphur doses, i.e. 0 (control) and $20 \mathrm{~kg}$ per hectare supplied through three sources, i.e. single superphosphate (SSP), gypsum and elemental sulphur was tested on three castor hybrids i.e. DCH- 177, HCH -6 and YRCH-1 to assess their suitability in the Central Dry Zone of Karnataka. The experiment was laid out in Randomized Block Design with three replications with net plot size $\left(3.6 \times 4.8 \mathrm{~m}^{2}\right)$ and gross plot size $\left(5.4 \times 6.0 \mathrm{~m}^{2}\right)$.

\section{Results and Discussion}

Effect of sulphur application yield components and seed yield

Among the treatments, application of sulphur at $20 \mathrm{~kg}$ per hectare through gypsum recorded significantly maximum seed yield (1388.8 $\mathrm{kg} / \mathrm{ha}, 1200.2 \mathrm{~kg} / \mathrm{ha}$ and $1250.9 \mathrm{~kg} / \mathrm{ha}$ for T4, $\mathrm{T} 8$, and T12, respectively) and oil yield of $(627.3,523.0$, and $558.1 \mathrm{~kg} / \mathrm{ha}$ for T4, T8 and T12, respectively) followed by application of sulphur at $20 \mathrm{~kg}$ per hectare through single super phosphate resulted in seed yield of (1273.1, 1125.8 and $1195.5 \mathrm{~kg} / \mathrm{ha}$ for T3, T7 and $\mathrm{T} 11$, respectively) and oil yield of (556.7, 464.7 and $496.9 \mathrm{~kg} / \mathrm{ha}$ for T3, T7 and T11, respectively) over control. This was due to higher number of spikes per plant, highest length of primary spike $(\mathrm{cm})$, more number of capsules per spike higher 100 seeds weight (g) and highest percentage of oil content in the seeds (Table 1).

Similar results were also reported by Srivastava (2007) who observed that application of sulphur at $20 \mathrm{~kg}$ per hectare through gypsum produced significantly higher seed yield (2577 kg/ha) in castor compared to no sulphur application (control $2087 \mathrm{~kg} / \mathrm{ha}$ ) under irrigated conditions of Uttar Pradesh. The treatment receiving sulphur at $20 \mathrm{~kg}$ per hectare through gypsum recorded significantly the higher yield over the control. In the present study, Control had registered significantly lower seed yield of (1082.2, 1012.5 and $1062.8 \mathrm{~kg} / \mathrm{ha}$ for T1, T5 and T9, respectively) owing to poor growth and yield components as a result of poor availability of nutrients from soil pool, as external supply was not done.

Assessment of different castor hybrids for their suitability in central dry zone showed that the hybrid DCH-177 with application of sulphur at $20 \mathrm{~kg} / \mathrm{ha}$ through gypsum recorded 
significantly the highest seed and oil yield $(1388.8 \mathrm{~kg} / \mathrm{ha}$ and 627.3 , respectively) followed by YRCH-1 $(1250.9 \mathrm{~kg} / \mathrm{ha}$ and 558.1 , respectively) and HCH-6 (1200.2 kg/ha and 523.0, respectively) with application of Sulphur at $20 \mathrm{~kg}$ per hectare through SSP over control under rainfed conditions, this was due to sulphur plays an important role in the formation of amino acids, synthesis of proteins, chlorophyll, oil content and nutritive quality, in turn it enhanced the higher spike length and more number of capsules per spike.

Table.1 Effect of different source of sulphur on seed yield $(\mathrm{kg} / \mathrm{ha})$, oil yield $(\mathrm{kg} / \mathrm{ha})$ and yield attributing characters of caster hybrids

\begin{tabular}{|c|c|l|l|l|l|l|l|}
\hline Treatments & $\begin{array}{l}\text { Number } \\
\text { of } \\
\text { spikes } \\
\text { /plant }\end{array}$ & $\begin{array}{l}\text { Length of } \\
\text { primary } \\
\text { spike } \\
\text { (cm) }\end{array}$ & $\begin{array}{l}\text { Number } \\
\text { of } \\
\text { capsules } \\
\text { /spike }\end{array}$ & $\begin{array}{l}\mathbf{1 0 0} \\
\text { seed } \\
\text { weight } \\
\text { (g) }\end{array}$ & $\begin{array}{l}\text { Oil } \\
\text { content } \\
(\mathbf{\%})\end{array}$ & $\begin{array}{l}\text { Seed } \\
\text { yield } \\
\text { (kg/ha) }\end{array}$ & $\begin{array}{l}\text { Oil yield } \\
\text { (kg/ha) }\end{array}$ \\
\hline T1 & 4.30 & 32.10 & 40.23 & 24.60 & 39.12 & 1082.2 & 423.3 \\
\hline T2 & 5.20 & 34.50 & 42.22 & 25.00 & 41.90 & 1163.2 & 487.3 \\
\hline T3 & 5.43 & 35.37 & 43.52 & 27.60 & 43.73 & 1273.1 & 556.7 \\
\hline T4 & 6.17 & 37.43 & 45.27 & 29.90 & 45.17 & 1388.9 & 627.3 \\
\hline T5 & 3.80 & 30.60 & 37.65 & 24.10 & 37.20 & 1012.2 & 376.5 \\
\hline T6 & 4.17 & 32.57 & 40.67 & 24.00 & 39.10 & 1095.2 & 428.2 \\
\hline T7 & 4.70 & 33.17 & 41.83 & 26.10 & 41.28 & 1125.8 & 464.7 \\
\hline T8 & 5.30 & 35.33 & 43.42 & 27.80 & 43.58 & 1200.2 & 523.0 \\
\hline T9 & 4.10 & 31.30 & 39.03 & 24.20 & 38.40 & 1062.8 & 408.1 \\
\hline T10 & 4.77 & 33.13 & 41.33 & 24.20 & 40.54 & 1122.0 & 454.8 \\
\hline T11 & 5.17 & 34.05 & 42.27 & 26.80 & 41.57 & 1195.5 & 496.9 \\
\hline T12 & 5.97 & 36.38 & 44.20 & 28.50 & 44.62 & 1250.9 & 558.1 \\
\hline S.Em \pm & $\mathbf{0 . 9 6}$ & $\mathbf{1 . 2 4}$ & $\mathbf{1 . 5 2}$ & $\mathbf{0 . 9 3}$ & $\mathbf{1 . 7 2}$ & $\mathbf{3 2 . 4 0}$ & $\mathbf{1 4 . 2 5}$ \\
\hline C.D. @ 5\% & $\mathbf{N S}$ & $\mathbf{2 . 5 2}$ & $\mathbf{3 . 8 2}$ & $\mathbf{2 . 2 5}$ & $\mathbf{4 . 3 3}$ & $\mathbf{9 2 . 5 2}$ & $\mathbf{4 1 . 4 2}$ \\
\hline
\end{tabular}

Treatment details

T1: DCH-177 + NO sulphur (RDF)

T2: DCH-177 + Elemental sulphur $20 \mathrm{~kg} / \mathrm{ha}$

T3: DCH-177 + SSP $20 \mathrm{~kg} / \mathrm{ha}$

T4: DCH-177 + Gypsum 20 kg/ha

T5: HCH-6 + NO sulphur (RDF)

T6: HCH-6 + Elemental sulphur $20 \mathrm{~kg} / \mathrm{ha}$

T7: HCH-6 + SSP $20 \mathrm{~kg} / \mathrm{ha}$

T8: HCH-6 + Gypsum 20 kg/ha

T9: YRCH -1 + NO sulphur (RDF)

T10: YRCH-1 + Elemental sulphur $20 \mathrm{~kg} / \mathrm{ha}$

T11: YRCH-1 + SSP $20 \mathrm{~kg} / \mathrm{ha}$

T12: YRCH-1 + Gypsum 20 kg/ha

The lower seed yield under control plots might be due to the fact that soil may not able to meet the nutrients demand of the crop and consequently resulted in poor growth and yield. Similar results were also reported by
Srivastava and Jagdish Kumar (2015) under irrigated conditions of Uttar Pradesh and Anonymous (2012). Similar findings were also made by Jamal et al., (2009) and Ahmad \& Rashid (2003) who observed that 
application of sulphur it is one of the key macro elements essential for plant growth and its requirement for oilseeds is usually higher than cereals and legumes.

Soil nutrient mining is major threat to modern agriculture as soil fertility is continuously depleting as a result of cultivation of high yielding varieties. Regular sulphur fertilization is needed to avoid further sulphur depletion in the top soil and thus to guarantee high crop productivity in the future. Castor hybrid DCH- 177 with Application of 100\% recommended NPK + Sulphur at the rate of $20 \mathrm{~kg}$ per hectare as gypsum found to mitigate the adverse effects of sulphur deficiency in castor crops and it could enhances the seed yield more effectively and the same caster hybrid performed well in the central Dry Zone of Karnataka.

\section{References}

Anonymous, 2015, Directorate of Economics and Statistics, Department of Agriculture and Cooperation, Ministry of Agriculture, Govt. of India.

Jamal, A., Ko, K., Kim, H. S., Cho, Y. K. and Joung, H. (2009). Role of genetic factors and environmental conditions in recombinant protein production for plant molecular farming. Biotech Advance, 27(6): 914-23.

Singh, A. K. and Singh, S., 1999, Response of oilseeds and pulses to indigenous sulphur sources in Bihar plateau. Fert. News, 44(7): 23-26.

Singh, M. V., 1991, Sulphur management in Agricultural Soils. Indian Institute of Soil Science, Bhopal, India, p.52.

Srivastava, S. K. (2007). Constraints and strategies for castor production in Uttar Pradesh. In National Seminar on Changing Vegetable Oils Scenario: Issues and Challenges before India. Jan, 29-31, 2007. Indian Society of Oilseeds Research, DOR, Hyderabad. pp. 422424.

Tandon, H. L. S., 1995, Sulphur deficiency in oilseeds. J. Agric. Sci., 11: 155-161.

Tomar, U.S., Badaya, A. K., Tomar, I. S., Vani, D. K. and Ambavatia, G. R. 2000, influence of different levels and sources of sulphur on growth and productivity of castor (Ricinus communis. L). Crop Res. 19(1): 142-143.

Anonymous, 2012, Annual Report 2011-12, Castor. Directorate of Oilseeds Research, Hyderabad. Pp. 80-81.

Anonymous, 2012, Annual Report 2011-12, Castor. Directorate of Oilseeds Research, Hyderabad. Pp. 80-81.

\section{How to cite this article:}

Muneshkumar, V. Kugati, Basavalingaiah, L.B. Ashok, M. Dineshkumar and Raveesha, S. 2019. Assessment of Performance and Suitability of Different Castor Hybrids (Ricinus communis L.) in Central Dry Zone of Karnataka, India. Int.J.Curr.Microbiol.App.Sci. 8(08): 358-361. doi: https://doi.org/10.20546/ijcmas.2019.808.040 